\title{
EXPLORING THE INFLUENCE OF VALUES IN THE SMEs SUCCESS
}

\author{
Ph.D. Ylvije (BORIÇI) KRAJA ${ }^{1}$ \\ Prof. Dr. Elez OSMANI ${ }^{2}$ \\ ${ }^{1}$ University "LuigjGurakuqi", Faculty of Economy, Department of Business Administration, Shkodër, ALBANIA \\ ylvije.kraja@unishk.edu.al \\ ${ }^{2}$ University "LuigjGurakuqi”, Faculty of Economy, Department of Finance, \\ Shkodër, Albania \\ elez.osmani@unishk.edu.al
}

\begin{abstract}
Nowadays, while COVID 19 pandemic is spreading rapidly, one of the challenges of small and medium enterprises is how to survive and to sustain being successful. SMEs are more sensitive to changes from pandemic, crises, and react faster than large enterprises. This situation has evolved in many small and medium enterprises, their owners, managers, employers, employees and customers. It is important to highlight that they stand together, not only during the pandemic situation, but they will always understand the situation with their businesses, and rapidly assess the value of things. It has been clear, for at least 30 years, the challenges that Albanian's SMEs face in competing with the rest of the enterprises in the region and further on.

Small and medium enterprises, in order to survive, must be innovative, flexible, creative and eagerly adjustable to new changes, just to be able to succeed. It is important to underline that SMEs values drive business and encourage everyone to achieve goals.

The main objective was to explore the impact of values created by managers, by employees and using high technology in the SMEs success. To evaluate how important, it is when businesses have some sort of values that make them successful and go beyond what competitors possess.

Based on literature and in some studies regarding the value, there was room to study the impact that value has in the SMEs success. Based on the data collected from participants of small and medium enterprises in Albania, the regression analysis is done, by using SPSS, 23. The study showed a positive correlation between value and SMEs success. This research was limited to only formal SMEs, the sampling has not included informal SMEs. It would have been beneficial to extend the study through the entirety of the businesses in order to also reflect the views and practices of informal SMEs, which are not significant in number.

Findings contribute to a better understanding of values created on SMEs. They are clearly visible for businesses and demonstrate the necessities of knowing and evaluating factors that raise values. Findings have some practical implication for managers. Some conclusions and recommendations are given to the representatives of businesses and even to the researchers. Managers should be sensitive toward values created by them in everyday work. From an academic standpoint, findings showed that value played a significant role in success of the SMEs.
\end{abstract}

Key words: value, value creation, chain value, SMEs, customers.

JEL classification: M13, D20, L84, O31, O32

\section{Introduction}

SMEs have played a significant role in supporting and driving the economic development of countries. SMEs constitute the main source of materials, ideas, processes and services that large enterprises cannot or do not want to do (Keskin Senturk, 2010). Small and medium enterprises are growing and blooming everywhere in those last years. SME-s play an important role in developed countries with advanced private sector and competitive markets (Bestvinova

et

al., 2011). According to Nelson \& Millet (2001), small and medium enterprises are facing with the same competitive problems as large organizations, but the difference is that they have limited sources and not well-prepared and qualified staff. Small and medium enterprises, family and non-family businesses, managers, as well as employees, become more conscious of the company's changing priorities and of the importance of having increased value of businesses. From another perspective, enhanced values bring a high level of trust that serves as tool on creating sustainable businesses. 
Nowadays, value creation through using different paths and ways is one of the main aims of the small businesses. Considering that the succession transition determines significant changes in SMEs in terms of engagement, succession has been interpreted as a process of creating values. Values unconsciously direct our attitudes and furthermore our behavior; we behave in a certain way, but cannot necessarily reason why (Schein, 2009).

In line with the theoretical framework derives the following hypothesis:

Hypothesis: Value has a significantly positive influence on success of SMEs.

The main objective of this research is to explore the positive impact that value has on the SMEs success. Interviews are considered a data source because they are the main source of information (Saunders et al., 2007). The study relied on both quantative and qualitative methods including survey questionnaire and interviews.

\section{Theoretical background}

The SMEs play a great role in the economic and social development of the country. SMEs play a key role in Albania by generating employment, innovation, competition and creating economic wealth (Kraja Boriçi Y., 2018). They are considered flexible, effective, progressive and important in an economy (Gal, 2007). Based on Kuratko (2016), every individual who wants to become an entrepreneur must demonstrate certain values such as applicability, trustworthiness, honesty, and confidence. According to Appiah, Possumah, Ahmat, and Sanusi (2018), entrepreneurial characteristics can be divided into five determinants which influence business performance: demographic characteristics, individual characteristics, personal characteristics, entrepreneurship orientation, and entrepreneurial readiness.

Performance relates to success. Performance is a complex and multi-dimensional phenomenon. Motivated and competent employees are essential in maintaining an effective organizational culture and improving performance in the organization (Eaton \& Kilby, 2015) The performance management must be in line with the company's long-term policies (Kandula, 2006).

\section{Value}

Woo, H.K (1992) provides four definitions of value: First, value means what is valuable to humans in the wider context of the well-being and survival of individuals and the wider of all species. Second, what society as a whole considers important can be considered value. Third, value refers to what individuals find valuable to own, strive for, or exchange. Fourth, value refers to the amount of usefulness that consumers see. Grönroos (2000) underlines that core value and added value have to be differentiated, whereby the core value means the benefits of a core solution compared with the price paid for that solution and the added value is created by additional services in the relationship compared with the relationship costs that occur over time. Economic value is simply the difference between the benefit received from a customer purchasing a firm's products or services and the full cost of those products and services (Barney \& Hesterly, 2010).

Kuron et al. (2015) explain that the values are parameter or indicator of anything which are considered important or desirable by the individual for life or work. Furthermore Krause, (2015) divides the values into two main groups: (1) organizational values - which serves as a guide for all people in the organization in making daily decisions, and (2) individual values - a set of standards by which individuals make decisions, evaluating others, explaining something or taking action and also assessing which are valuable, important, or preferably on behavior, preferences or specific action. Values operate as broad, emotionally charged motivational goals, directing attention and energy toward personally meaningful actions (Grant and Rothbard, 2013). 
In general, a firm has a competitive advantage when it can generate more economic value than its rival firms (Barney $\&$ Hesterly, 2010). The magnitude of a firm's competitive advantage is the difference between the economic value that a firm can create and the economic value that its rivals are able to create (Barney \& Hesterly, 2010). First of all, it is the organization's ability to create value, formulate and implement a successful strategy, even in the case of lack of innovation Porter (2011), points out that what is good for the community is good for the business as well as the creation of economic value by the creation of social value.

From consumers' point of view, the value of products and services can be determined by their problem-solving efficiency which is subjective and likely to mean different values for each customer and related to customer expectation (Demeter et al. 2010).

Tallon et al (2000) argued that IT provides value at the business process level through improved inventory management, greater product variety, and enhanced customer service.

Carr (2003) is one of many to turn the research spotlight by questioning the value gained from investments in IT, and there is considerable literature on the IT productivity paradox that examines "IT investment" and its relationship with firm performance. Rather than focus on IT investment", Devaraj and Kohli (2003) chose to focus on "use of technology"e and found that IT payoffs can be found and measured. Value of an idea or IT depends from business model (Chesbrough 2006).

Values are the core element of organizational culture (Gaikwad S., 2013). Business values are important factors to establish an effective organizational culture and to improve performance in the SMEs. Values and capabilities are developed through a process of learning where employees of a firm repeatedly enhance their experiences in solving problems (Kraja Boriçi, Y., 2018). Values are great driving forces for everyone, buyers or sellers, employees or employer, pushing them to do their best. SMEs need to identify the values they possess, and they should endeavor to turn them into success in their business. Yunus and Tadisina (2016) noted that in an effective organizational culture, business managers use core values to improve performance and productivity.

\section{Value creation}

A firm create greater economic value when it has competitive advantage (Peteraf M.A.,1993). Grönroos (2011) define value creation as a process which helps customers to be better off in some way or the process that enhances customer's wellbeing. Value creation is also defined as a difference between willingness to pay and the level of use value and exchange value (Bowman \& Ambrosini, 2010). And value for customer as defined by Füller, et al (2011) is greater satisfaction of consumer. The notion of value creation can be sometimes understood narrowly, focusing only on customer value, or value created in production (Chatain, 2010). More specifically, "value creation is the act of obtaining rents (widely defined as financial, social, or personal) that exceed the total costs (which may or may not include average rates of return for a particular industry) associated with that acquisition" (Bamford, 2005, p. 48). Low cost is related to efficiency, quality, innovation, customer responsibility, etc. SMEs that have low cost, high quality, innovation and are efficient have a competitive advantage (Hill \& Jones, 1998). According to Porter (1980) low cost and differentiation are the two basic strategies for creating value and providing competitive advantage. Hamel (2000), argues that innovation is a very important component of a firm's strategy. Innovation has been considered an important factor in creating competitive advantage (Stalk, 2006). To drive future efforts of value creation, firms must assess their ability to effectively deliver value to customers that will increase and repeat in scale in the future, thereby (Chambers and Patrocinio, 2011).

Actually in a business generating, profit, wealth first requires creating value and then the main point of the business is not only to create value but even to capture the value. Nambisan and Baron (2007) thus, explain value as reduced 
risk for the firms and consumers. Organizations today are characterized by a complex relationship of different actors, so it is important to establish competitive advantages and create value by managing efficiently the missing resources in order to cope with fierce competition and to successful confront the challenges faced by SMEs (Kraja Boriçi. Y., 2018). Value creation is a starting point for all businesses new or established ones. Sometimes managers instead of increasing value, decrease value by taking decision in the short-term and not in the long-term, losing in this way the value of their business. According to Thakor (2000), individuals who get ahead the fastest, have the greatest energy and enthusiasm and are the happiest at work are typically those who are the most effective value creators. Innovation reflects the trend of the business that is supported in new ideas, experiments and creative processes that could be concluded in new products, services or high technologies (Lumpkin \& Dess, 1996). SMEs play an important role in promoting innovations of new technological developments (Wang \& Wu, Chunyou; 2011). SMEs may be seen to over-invest, under-invest or mis-invest in technology. Determining the most appropriate rate of investment in technology is not an easy task for enterprises.

\section{Value creation to consumers}

Within firm's there is room to create value and to be innovative, if everyone could be open mind in doing things just a little better that were done up to now. Consumers are the best judge of value creations. Customers are not considered to be passive targets of market but they act as an active operant resource which are in power to create and determine value in the various value creating process, their role can be reconfigured from consumer to the one who contributes and creates value (Tapscottand Williams, 2006). According to (Hill \& Jones, 2010) a company that increases the value of its product in the eyes of consumers has more pricing options: it can raise prices to reflect value or keep prices lower to drive customers to buy its products, thereby increasing its sales volume. Creation and delivery of values for customer takes place within a specific system. It includes defining values for customers, shaping value proposition adjusted to their needs, communicating and delivering value propositions to customers and controlling the use of the value obtained by customer (Kotler, 2005). According to Coplin (2002) it is very important that in today's competitive environment, for a firm to have a sustainable competitive advantage, it must above all provide value to customers. The validity of information depends on the characteristics of the education level, the quality of the infrastructure and the communication systems (Deakins, 2006). Close contacts with customers can assist in creating positive outcomes, for example, in terms of innovativeness, customer satisfaction and value (Chu et al. 2016). According to (Saunila, et.al 2017) today, an increasing number of goods and services are sold in digital form. Because of the intangible nature of digital offerings, value creation differs from traditional goods and services offerings. This requires new strategies and ways of operating in companies to ensure that they remain focused on their customers and not on their own internal processes. "Value creation processes convert firm resources into consumer value" (Chikán, 2008). According to Blocker and Flint (2007), companies are facing intense rivalry based on what customers currently value. The customer alone creates value in using the product or service, which can be called value-in-use (Grönroos and Voima 2013). Oksanen et al. (2010) have defined that value net is the entity that brings together the different capabilities and resources to produce the actual output. Therefore, a value net is formed around customers and it can respond reliably and rapidly to customer preferences (Bovet and Martha, 2000).

\section{Value chain analysis}

Creating more customer value is essential for any activity of a company; this process is called the Value Chain (Kotler $\&$ Keller 2009.) Value added through differentiation is a powerful tool for achieving market advantage (Banabakova, 2004). Other factors may also create product differentiation such as time, location, division of activities between business units, learning, integration and institutional factors Porter (1985). According to Porter, different strategy, could add value. Chain value is used to identify and to coordinate oriented activities, to offer high quality products and socially useful services (Karbownik et al., 2012). The term value chain, according to John \& Hill (2010), refers to the idea that a company is a chain of activities for transforming inputs into outputs that consumers value. The value 
chain has been used to identify and coordinate activities directed to deliver high quality products and socially useful services (Karbownik et al., 2012).

Ravald \& Gonroos (1996) in their study concluded that the reason consumers might have different perceptions of value is due to different personal values, needs and preferences as well as the financial resources they have. The validity of the information depends on the characteristics of educational level, quality of infrastructure and communication systems (Deakins, 2006)

While a study conducted by Linden et al. (2009), who have reviewed the case of the Apple iPod, it turns out that value is created as a result of using high technology to sell products to consumers.

Based on a study realised by Valle et al. (2010), (MIT Sloan Management Review dhe IBM, Instituti për vlerat e biznesit) who observed about 3000 executive managers that were involved in 30 different industries, in 100 hundred countries. It was obviously shown that managers are worried if they are getting enourmous value within their organizations. Based on this study it resulted that information, value creation from the organization was an priority.

In his study, Rummukainen M. (2011), considered a case of online services provided by Whitevector Ltd. in Helsinki, Finland. He considered where value is created in the global value chain. The value added by Whitevector was largely achieved through the provision of online service, with little need for physical infrastructure.

From an academic standpoint, finding showed that value within organizations have great impact to the businessess, lower business risk (Maklan et al., 2008), low costs, better productivity and revenue growth (Ramaswamy and Gouillart, 2010); innovative competitive skills (Whiteley and Hessan, 1996); greater commercial potential along with wider acceptance of product in the market (Oldemaat, 2013); and reduced uncertainty (Prahalad and Ramaswamy, 2004b).

To conclude, from the above literature review, nowadays the performance is related to bunch of factors, but let see that value has great impact on small and medium enterprises, SMEs.

\section{Analysis of data}

The data for the study comes from face-to-face interviews with owners, managers, leaders, administrative staff of the business using semi-structured interview questions. A part of the questionnaires that were filled in electronic version, were self-filled by the participants. The collection of data for the study was carried out by using a questionnaire which included several from the seven-point Likert scale. The population of the study consisted of a final sample of 725 small and medium enterprises from different SMEs in Albania.

Pilot testing of the study was carried out by collecting primary data with the help of questionnaire distributed to 17 SMEs representatives.

Based on the data on the graphic, it is obvious that the service sector is the main type of business regarding to the small and medium enterprises. 


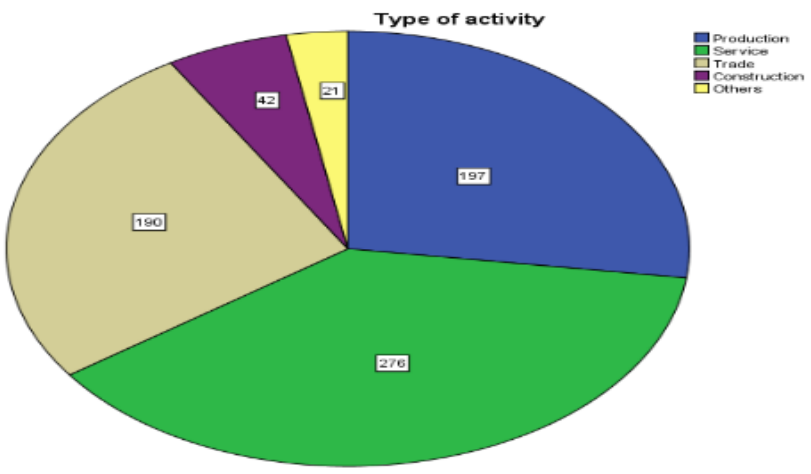

In this case was used the Varimax rotation analysis method. Cronbach's Alpha was computed to assess reliability. Cronbach Alpha is the reliability coefficient that assess the consistency of the entire scale (Hair et.al.1998).

"Performance" is measured as the average of the three questions; as ROI, income and market share. An exploratory factor analysis was carried out, using the "Varimax rotation analysis" method. By the factorial analysis the 3 questions results in a component which accounts for $66,56 \%$ of the total variance. In our case, Cronbach's Alpha was 0.748 .

The results of this analyze are given in the Table 1.

Table 1: Factor analysis Cronbach's Alpha, is 0,748 .

\begin{tabular}{|l|l|}
\hline Performance & \\
\hline ROI & 0.814 \\
\hline Income & 0.824 \\
\hline Market share & 0.810 \\
\hline
\end{tabular}

Questions are measured based on a Likert scale from 1- 7 "Strongly Important" to "Strongly Unimportant".

"Value" measured as average of 3 questions; as value created by management, value created by employees and value created by using innovation- high technologies, IT. It was conducted again, an exploratory factor analysis using the method of analysis with rotation Varimax. Questions resulted in a component, amounting for $59.83 \%$ of total variance. Realibility coefficient Cronbach's Alpha was 0.658 . The result of this analysis are demonstrated in Table 2.

Table 2: $\quad$ Factor analysis- Cronbach's Alpha 0.658

\begin{tabular}{|l|l|}
\hline Value & \\
\hline Value created by management & 0.820 \\
\hline Value created by employee & 0.825 \\
\hline Value created by usig high tech & 0.664 \\
\hline
\end{tabular}

Questions are measured based on a Likert scale from 1 - 7 "Strongly Important" to "Strongly Unimportant".

The linear regression analysis was used to examine the impact of value on the business success. 
ISSN 2661-2666 (Online) International Scientific Journal Monte (ISJM) DOI: 10.33807/monte.202120

Volume 5, (No).2 (2021): December

Table 3: Linear regression analysis for the "performance of SMEs" depended variable.

\begin{tabular}{|c|c|c|c|r|}
\hline Model & $\mathbf{R}^{\mathbf{2}}$ & Adjusted $\mathbf{R}^{\mathbf{2}}$ & t value & Sig. \\
\hline & 0.25 & 0.249 & & \\
\hline (constant) & & & 20.938 & 0.000 \\
\hline value & & & 15.519 & 0.000 \\
\hline
\end{tabular}

The $\mathrm{R}^{2}$ squared correlation coefficient is 0.250 , which is also referred to as the coefficient of determination. This value indicates the percentage of total variation of $\mathrm{Y}$ explained by $\mathrm{x}_{1}$.

Regression equation in our case is the following.

$$
Y=\beta+\beta x
$$

$\hat{Y}=$ dependet variable, "performance"

$\mathrm{x}_{1}=$ predictor "value"

Using the unstandardized regression coefficient, or beta, regression equation can be presented as follows:

$$
\text { "performance" }=2,320+0,383 \text { "value" }
$$

Coefficient of the independent variable "value" is positive, which entails that it has a positive impact on the SMEs performance, which means the increase in the level of the independent variable will increase the level of the depended variable "performance". According to linear reggresion, Table 3, it results that independet variable is statistically significantly. Based on this analyze it results that independent variable "value", explains $25 \%$ of the variance of the dependet variable "performance" $\left(\mathrm{R}^{2}\right.$ adjusted $\left.=0.250\right)$ and this is not by chance. Unstandardized coefficient is $\left(B_{1}=0,383\right)$. Results show that regression model of the $F=240.831$ become well matched and has meaning for $(p=0,00)$ significance level of $(0,05)$, because in this case $p=0,000$ is less than 0,05 . By using statistical test of controlling of the individual regression coeficient is taken the same result $\left(t_{1}=15,519\right.$ and $p=0,000$; this coeficient is different by zero which means it contributes to this model. As it can be comprehended, $\left(B_{1}=0,383\right)$ unstandertizied coefficient of value is positive, which means it has great impact on the SMEs success.So, conslusion, $\mathrm{H}_{1}$ : is supported.

\section{Limitations of the study}

This study has limitation. Pertaining the quantitative stage, there is a considerable number of firms 725 , that were included in filling out the questionnaries, which does not reflect all points of view and practices of small and medium enterprises in Albania. It is not representative of the whole small and medium enterprises in Albania.

Another limitation might have to do with questionnarie. In the most part questionnaries was self-administerd by the participants, which means it was fill out by them even if they had any question.

It also presents opportunities for further research, particularly in terms of further testing and including even other factors that could influence value and could contribute in performance. Of course there are other factors that maybe subject of any further study.

\section{Conclusions and recommandations}

The study showed a positive correlation between value and SMEs success. This result is supported even by different researchers who positively evaluate the impact of value factors on SMEs.

From an academic standpoint, findings showed that values play a significant role in success of the SMEs. Managers should be sensitive toward values created by them in everyday work. Managers ought to be flexible, innovative, well- 
quiped with knowledge, capable to change the way they act and make decisions, if they want their business to have success.

Should be increased the responsibility of local and central government towards small and medium enterprises. Ensuring political stability will encourage expansion of SMEs in other cities of the region. Local government should support formal businesses, and meantime should draw policies and practices to stop growing up the informal businesses (Kraja Borici Y. \& Osmani E., 2014). A lot should be done to decrease the number of informal businesses.

One of the most important things that owners, managers and leaders can do is to communicate time after time with their employees. This would boost their confidence, make them more productive, more creative, contributing in this way in the business performance.

It is important to highlight that business managers ought to enhance their business performance by establishing effective organizational ways to create values. More attention is also needed to the quality of value. Systematic and continuous analyses of firms' resources and needs are required, in which businesses themselves should be deeply involved. Overall, there is a strong view that value leads to increased SMEs success.

\section{References}

\section{$\underline{\text { Books }}$}

Analoui F. \&Karami A., (2003), 'Strategic Management'. In small and Medium Enterprises. Thomson Learning 2003.

Barnes, Y. B. \& William S.H., (2010), 'Strategic Management and Competitive Advantage. Concepts and cases'. Third Edition. Prentice Hall fq.10

Gregory G.D, Lumpkin G.T. \& Taylor M.L. (2005). "Strategic Management". 2 ed. New York: McGraw-Hill Irwin.

Hair, J.F., Anderson, R.E., Tatham, R.L. \& Back, W.C., (1998). Multivariate Data Analysis, Fifth Edition, Publisher: Prentice Hall.

Hill Ch.W.L., \& Jones G.R., (2008),'Strategic Management Theory, An integrated approach, 9th Edition, South Western Cengage Learning

Kotler,P (2000),'Marketing Management Analysis, Planning and Control', Fifth Edition, Prentice Hall. Englewood Cliffs, New Jersey

Lev, B. (2001) Intangibles. Management, Measurement, and Reporting. Washington D. C., Brookings Institution Press. Washington D.C, www.brookings.edu

Saunders M, Lewis P, Thornhill A (2007). Research Methods for Business Students, 4th ed., London, FT Prentice Hall Wheelen, Th.L. \&Hunger, D.J., (2012), 'Concepts in Strategic Management and Business Policy', Toward Global Sustainability, Thirteenth Edition. Pearson.

\section{$\underline{\text { Journal article }}$}


ISSN 2661-2666 (Online) International Scientific Journal Monte (ISJM) DOI: $10.33807 /$ monte.202120

Volume 5, (No).2 (2021): December

Ab Hamid, M.R.; Mustafa, Z.; Idris, F.; Abdullah, M.; Suradi, N.M.; Ismail, W.R. Multi-factor of cultural values: a confirmatory factor analytic approach. Qual. Quant. 2013, 47, 499-513.

Appiah, M. K., Possumah, B. T., Ahmat, N., \& Sanusi, N. A. (2018). External Environment and SMEs Investment in The Ghanaian Oil and Gas Sector. Economics \& Sociology, 11(1), 124-138.

Bamford, C. E. (2005). Creating value. In M. A. Hitt \&R. D. Ireland (Eds.),The Blackwell ncyclopedia of management: Entrepreneurship (pp. 48-50). Oxford, UK: Blackwell Publishers

Barney J., (1991), 'Firm Resources and Sustained Competitive Advantage' Journal Management 1991, Volume 17, $\mathrm{N} 1,99-120$

Barney, J.B\& Mackey, T.B., (2005). 'Testing resource-based theory'. In research Methodology in Strategy and Management. Vol 2. fq 1-1

Bettencourt L.A. (2010), Service innovation: How to go from customer needs to breakthrough services'. McGraw Hill Companies, fq.202.

Bibu N., Petru S., Sala D., (2009),"External and Internal Environment Influences on SME Competitiveness from the Western Area of Romania'. Scientific paper, Vol. 6. Nr 2, fq.41-52.

Blocker, C. P. \& Flint, D. J. 2007. Exploring the dynamics of customer value in cross-cultural business relationships. Journal of Business \& Industrial Marketing, vol. 22, issue 4, pp. 249-259.

Carr, N., IT Doesn"et Matter, Harvard Business Review, May 2003, pp. 1-17.

Bovet, D. and Martha, J. (2000). Value nets: Breaking the supply chain to unlock hidden profits, New York: Wiley \& Sons.

Chambers, E., and Patrocinio, A. M. (2011). Business Models and Value Creation: A Case Study of the New York City Economic Development Corporation. Umea, Sweden: UMEA Universitet

Chikán Attila [2008]: Vállalatgazdaságtan. Aula Kiadó, Budapest

Chu Z, Chu Z, Wang Q, Wang Q, Lado AA, \& Lado AA (2016) Customer orientation, relationship quality, and performance: The third-party logistics provider's perspective. The International Journal of Logistics Management 27(sn3):738-754.

Collins DJ, Mongomery CA, (1995), Competing on Resources: strategy in the 1990s. Harvard Business Review 73 (4): $118-128$

Conway, J.M., \& Huffcutt, A.I. (2003). A review and evaluation of exploratory analysis practices in organizational research. "Organizational research methods" 6 (2), 147-168.

Coplin, H.C.L., (2002),"Competitive advantage and the SME': The role of the distinctive competences as the determinants of success are there differences across gender, sector and size" Spain.

Demeter Krisztina - Chikán Attila - Gelei Andrea - Kiss János - Losonci Dávid - Matyusz Zsolt - Nagy Judit Schubert Anikó - Venter Lóránt - Vörösmarty Gyöngyi - Wimmer Ágnes [2010]: Az értékteremtés folyamatai, termelés, szolgáltatás, logisztika jegyzet. Vállalatgazdaságtan Intézet, Budapesti Corvinus Egyetem 
ISSN 2661-2666 (Online) International Scientific Journal Monte (ISJM) DOI: $10.33807 /$ monte.202120

Volume 5, (No).2 (2021): December

Devaraj, S., and Kohli, R. (2003). Performance impacts of information technology: is actual usage the missing link? Management Science, 49(3), 273-289.

Denzin, N.K. \&Linconl, Y.S., (2005).'The SAGE handbook of qualitative research'. Thousand Oaks, Sage Publications.

Gaikwad S., (2013).“The Role of Values in Unforeseen Circumstances of Business” IOSR Journal of Business and Management (IOSR-JBM) e-ISSN: 2278-487X, p-ISSN: 2319-7668 PP 49-55 www.iosrjournals.org

Gal M., (2007), 'Venture capital as financial source for SMEs in transitive economy of Slovakia and Hungary'. University of Miskolc Faculty of Economics. Doctoral school "Enterprise Theory and Practice' Miskolc, 2007

Grant, A. M. and Rothbard, N. P. (2013). When in Doubt, Seize the Day? Security Values, Pro Social Values, and Proactivity Under Ambiguity. American Psychological Association.

Grönroos, C. (2011). Value co-creation in service logic: A critical analysis. Marketing theory, 11(3), 279-301.

Grönroos, C., \& Voima, P. (2013). Critical service logic: making sense of value creation and cocreation. Journal of the Academy of Marketing Science, 41(2), 133-150.

Henderson, R. \& Cockburn I., (1994), 'Measuring Competence. Exploring Firm Effects in Pharmaceutical Research. Strategic Management Journal. 15, 63-84. https://doi.org/10.1002/smj.4250150906

Kandula, S. R. (2006). Performance management. In Performance management. Strategy. Intervention. Drivers. (1st ed.). (p. 5). Asoke K. Ghosh.Kandula, S.R (2006): Performance management, New prentice Hall of India private Ltd New Delhi

Keskin H. \& Senturk C., (2010), 'The importance of small and medium - sized enterprises $\quad$ (SME) $s$ in the economies: SWOT analyses of the SME sector in Turkey and Albani, Niğde Üniversitesi IIBF Dergisi, Vol 3, Nr1, pg.116-132.

Kraja Boriçi Y., (2018). "The impact of tangible and intangible assets on the SMEs' success. The Albanian Case". Entrepreneurship in Post-Communist Countries. New Drivers Towards a Market Economy. Publisher: Springer International Publishing AG, part of Springer Nature 2018; https://www.springer.com/la/book/978331975906 ; https://doi.org/10.1007/978-3-319-75907-4

Kraja Boriçi Y. \& Osmani E. (2014). "The role of government policy in supporting SMEs". Academic Journal of Interdisciplinary Studies MCSER Publishing, Rome-Italy; E-ISSN 2281-4612 ISSN 2281-3993; Vol 3 No 2.; Doi:10.5901/ajis. 2014.v3n2p391

Kuron, L. K. J., Lyons, S. T., Schweitzer, L., Ng, E. S. W., Lyons, S. T., \& Schweitzer, L. (2015). Millennials“ Work Values: Differences Across The School to Work Transition. Personal Review, 44(5), 991-1009. http://doi.org/10.1108/PR-01-2014-0024.

Lumpkin G.T.,\&Dess G.G.,(1996), 'Clarifying the entrepreneurial
$\begin{aligned} & \text { construct and linking it to performance. Academy of } \\ & \text { (1). 135-172. }\end{aligned}$

Miller D. (2003). An asymmetry-based view of advantage towards an attainable sustainability: Strategic Management. Journal October Special Issues 24: 961-976. 
ISSN 2661-2666 (Online) International Scientific Journal Monte (ISJM) DOI: $10.33807 /$ monte.202120

Volume 5, (No).2 (2021): December

Miller, D. (1983). The correlates of entrepreneurship in three types of firms. Management Science, 29.

Miles, M. P. (2005). Competitive advantage. In M. A. Hitt \& R. D. Ireland (Eds.), The Blackwell encyclopedia of management: Entrepreneurship (pp. 36-37). Oxford, UK: Blackwell Publishers.

Naghi M.\&Szasz, L.,(2010). 'Impact of the Romanian industrial sector on the country's ecoomic performance. The Proceedings of the 3rd Internatioanal Conference. "Managerial Challenges of the Contemporary Society", Editura Risopring

Nunnally JC. 1978. Psychometric Theory (2nd edn). McGraw-Hill: New York

Oksanen, P., Hallikas, J. and Sissonen H. (2010) 'The evolution of value networks', International Journal of Networking and Virtual Organisations, Vol. 7, No. 4, pp. 381-398.

Peteraf M.A.,(1993), "The cornestones of competitive advantage: a sourcebased view", Strategic Management Journal, , 14: 179-191.

Saunila M. \& Rantala T. \& Ukko (2017); “Characteristics of Customer Value Creation in Digital Services" Journal of Service Science Research 9:239-258 DOI 10.1007/s12927-017-0012-4

Tallon, P. P., Kraemer, K. L., and Gurbaxani, V. (2000). Executives' perceptions of the business value of information technology: a process-oriented approach. Journal of Management Information Systems, 16(4), 173

Teece, D. J., Pisano, G., \& Shuen, A, 1997. Dynamic capabilities and strategic management. Strategic Management Journal, 18(7): 509-533.

Thakor, A. (2000). Becoming a better Value Creator: How to Improve the company's Bottom line and your own. University of Michigan Business School Management Series.

Wang C., Walker A.E.\&Redmond, J.'Explaining the Lack of Strategic Planning in SMEs', The importance of Owner Motivation. International Journal of Organisational Behaviour, Volume 12, Nr.1

Yunus, E., \& Tadisina, S. (2016). Drivers of supply chain integration and the role of organizational culture: Empirical evidence from Indonesia. Business Process Management Journal, 22, 89-115. doi:10.1108/BPMJ-12-2014-0127

\section{$\underline{\text { Website }}$}

Eaton, D., \& Kilby, G. (2015). Does your organizational culture support your business strategy? Journal for Quality and Participation, 37(4), 4-7. Retrieved from http://www.asq.org

Kotler Ph. (2005): Marketing. ISBN: 83-7301-532-9; V1, pg $754 \quad$ Rebis, Poznań https://eki.pl/index.php?br1=30000\&br2=30100\&detailed=REB065

Kuratko, D. F. (2016). Entrepreneurship: Theory, process, and practice (10th ed.). Boston: Cengage Learning https://www.amazon.com/Entrepreneurship-Practice-Donald-F-Kuratko/dp/1305576241

Valle et al. (2010), (MIT Sloan Management Review dhe IBM https://sloanreview.mit.edu/projects/analytics-the-new-path-to-value/

Porter M.E.,(1980), 'Competitive advantage', New York. Free Press. https://onlinelibrary.wiley.com/doi/abs/10.1002/smj.4250020110 